Aristotle's Prior and Posterior Analytics

A revised Text with Introduction and Commentary by W. D. Ross. Pp. $x+690$. (Oxford : Clarendon Press; London : Oxford University Press, 1949.) 42s. net.

TT would be both impertinent and inappropriate Io attempt any more than to accord to this monumental work the welcome which its origin and importance make obvious. To this perhaps may be added the gratitude of men of science-in the widest sense-to Sir David Ross for his labours, and no less for the gracious form in which they are presented. One hundred and forty-five years have gone by since the last critical edition of the "Analytics" was published; several studies have appeared during that time. These find their place in the present text, as well as the work of two of the great Renaissance scholars.

The rapid growth of many-valued logics in recent years brings to mind the need for continuous recollection of the rock whence they are hewn; it is not a little remarkable that-in many cases - the savants most creative in progressive researches are just those best versed in the long history of their subject. To them and their like this revised text, introduction and commentary should make its own special appeal.

F. I. G. RawLins

\section{Evolution of the Forebrain}

The Fundamental Anatomy of the Telencephalon with special reference to that of Testudo geometrica. By Dr. G. W. H. Schepers. Pp. xi+212. (Cape Town: Maskew Miller, Ltd.; London: John Clark, 1948.) $50 s$.

$\mathrm{T}$ the words of the author, this book concerns 1 itself with a complete re-analysis of the reptilian telencephalon as an aid to determining the manner and mechanism of the forebrain evolution. This telencephalon has attracted much interest on all sides from students concerned with the evolution of the forebrain.

The choice of Testudo geometrica lies with the general arrangement of the forebrain, suggesting primitiveness and a simplicity which are not due to a lack of any of the essential structural elements. The book endeavours to cover the work done in this field as a whole and at the same time make a careful analytical summary of the telencephalon of the Testudo geometrica.

The preface by Kappers gives an indication of the importance of this contribution, and the book must prove very valuable to students of brain research whether they be anatomist or physiologist.

\section{Faune de Belgique}

Poissons marins. Par Dr. Max Poll. Pp. ii +452. (Bruxelles: Musée Royal d'Histoire Naturelle de Belgique, 1947.) 420 francs.

T ONGCHAMPS (1842), Van Beneden (1871), Gilson (1921) and certain others have made contributions of greater or less importance to the knowledge of the marine fish fauna of Belgian waters. But not until the recent publication of "Poissons Marins" by Max Poll has any comprehensive and systematic work covering the subject as a whole been available. In this book, the author not only synthesizes the results of previous workers, but also makes important contributions of his own to the knowledge of species already familiar in the region and of others recorded there for the first time. In addition to reasonably full systematic descriptions of each species, there are also brief notes on time and place of spawning, seasonal and other migrations, food, habits and economic importance. The usual keys to aid identification are included, and the book is amply illustrated ; but some of the drawings could be improved upon. Nevertheless, this is a valuable publication.

G. A. Steven

\section{Mathematics}

A Text-Book for Technical Students. By Bevis Brunel Low. Second edition. Pp. vii +464. (London, New York and Toronto : Longmans, Green and Co., Ltd., 1948.) 17s. 6d. net.

WHE first edition of this excellent text-book appeared in 1931, and it has been reprinted several times. It is amazing how, in a single volume, the author contrived to give some account of algebra, logarithms, trigonometry, plane and solid co-ordinate geometry, geometrical conics, empirical laws, differential and integral calculus, differential equations, finite differences and Fourier's series. Now he has added a chapter on determinants. There are many worked examples throughout the book and nearly eight hundred examples for solution, with answers. The diagrams are exceptionally well drawn. The book will be of great value to technical students.

\section{The Birds of Concord}

By Ludlow Griscom. (New England Bird Studies, 2.) Pp. $x i+340+16$ plates. (Cambridge, Mass. : Harvard University Press; London: Oxford University Press, 1949.) 27s. $6 d$. net.

$7 \mathrm{HE}$ area dealt with is roughly one hundred square miles in north-east Massachusetts and is of special interest, since the great American naturalist William Brewster began his ornithological career there in 1868 and for nearly fifty years made continual observations. Brewster's diaries consist of fifty volumes and are now in the Museum of Comparative Zoology at Harvard. Since Brewster's death in 1919 others have carried on the work, so that there are unbroken observations on this area covering nearly eighty years.

The book is divided into two parts : (1) "Population Trends" and (2) "Birds of the Concord Region". In this latter part, in addition to the systematic list, there are interesting notes on migration routes, seasonal bird-life and newly created habitats. Part 1 deals with a variety of subjects; it is the most interesting section of the book and is well worth consideration by bird students in Great Britain. Starting with a description of the area, climate and vegetation, the author goes on to give details of the effect of civilization and disturbances. This section is of particular interest on account of the long period in which the area has been under close observation. The remainder of this part consists of remarks on the fluctuations in numbers of some birds and animals and the importance of adaptability, followed by some thirty pages on population, declines and increases.

Mr. L. Griscom does not agree that there are periodic cycles in birds and considers that in New England, at least, the winter irruptions of the snowy owl may be due to failure of food supply in the north or to over-population-this owl is a prolific breeder and lays from four to ten eggs. He also gives his reasons for the fluctuations of the ruffed grouse, and brings to a close his discussion on cycles with a note on some general principles of population trends. There are sixteen excellent photographs by various members of the National Audubon Society. 